\title{
Ubiquitous production of branched glycerol dialkyl glycerol tetraethers (brGDGTs) in global marine environments: a new source indicator for brGDGTs
}

\author{
Wenjie Xiao ${ }^{1,2}$, Yinghui Wang ${ }^{2}$, Shangzhe Zhou ${ }^{2}$, Limin $\mathrm{Hu}^{3}$, Huan Yang ${ }^{4}$, and Yunping $\mathrm{Xu}^{1,2}$ \\ ${ }^{1}$ Shanghai Engineering Research Center of Hadal Science and Technology, College of Marine Sciences, \\ Shanghai Ocean University, 201306 Shanghai, China \\ ${ }^{2}$ MOE Key Laboratory for Earth Surface Process, College of Urban and Environmental Sciences, Peking University, \\ 100871 Beijing, China \\ ${ }^{3}$ Key Laboratory of Marine Sedimentology and Environmental Geology, First Institute of Oceanography, \\ State Oceanic Administration, 266061 Qingdao, China \\ ${ }^{4}$ State Key Laboratory of Biogeology and Environmental Geology, China University of Geosciences, 430074 Wuhan, China \\ Correspondence to: Yunping Xu (ypxu@ shou.edu.cn)
}

Received: 1 June 2016 - Published in Biogeosciences Discuss.: 6 June 2016

Revised: 14 October 2016 - Accepted: 18 October 2016 - Published: 28 October 2016

\begin{abstract}
Presumed source specificity of branched glycerol dialkyl glycerol tetraethers (brGDGTs) from bacteria thriving in soil/peat and isoprenoid GDGTs (iGDGTs) from aquatic organisms led to the development of several biomarker proxies for biogeochemical cycle and paleoenvironmental reconstructions. However, recent studies reveal that brGDGTs are also produced in aquatic environments besides soils and peat. Here we examined three cores from the Bohai Sea, and found distinct difference in brGDGT compositions varying with the distance from the Yellow River mouth. We thus propose an abundance ratio of hexamethylated to pentamethylated brGDGT (IIIa / IIa) to evaluate brGDGT sources. The compilation of globally distributed 1354 marine sediments and 589 soils shows that the IIIa / IIa ratio is generally $<0.59$ in soils and $0.59-0.92$ and $>0.92$ in marine sediments with and without significant terrestrial inputs, respectively. Such disparity confirms the existence of two sources for brGDGTs, a terrestrial origin with lower IIIa / IIa and a marine origin with higher IIIa / IIa, which is likely attributed to a generally higher $\mathrm{pH}$ and the production of brGDGTs in cold deep water in marine waters. The application of the IIIa / IIa ratio to the East Siberian Arctic Shelf proves it to be a sensitive source indicator for brGDGTs, which is helpful for accurate estimation of organic carbon source and paleoclimates in marine settings.
\end{abstract}

\section{Introduction}

Glycerol dialkyl glycerol tetraethers (GDGTs), membrane lipids of archaea and certain bacteria, are widely distributed in marine and terrestrial environments (Schouten et al., 2013). These lipids have been a focus of attention of organic geochemists for more than 10 years because they can be used to estimate environmental variables in the past such as temperature, soil $\mathrm{pH}$, organic carbon source and microbial community structure (e.g., Schouten et al., 2002; Hopmans et al., 2004; Weijers et al., 2006; Lipp et al., 2008; Kim et al., 2010; Peterse et al., 2012; Zhu et al., 2016). There are generally two types of GDGTs, isoprenoid (iGDGTs) and nonisoprenoid, branched GDGTs (brGDGTs; Fig. 1). The former group is more abundant in aquatic settings, and generally thought to be produced by Thaumarchaeota, a specific genetic cluster of the archaea domain (Sinninghe Damsté et al., 2002; Schouten et al., 2008), although Euryarchaeota may be a significant source of iGDGTs in the ocean (e.g., Lincoln et al., 2014). In contrast, the 1,2-di- $O$-alkyl-sn-glycerol configuration of brGDGTs was interpreted as evidence for a bacterial rather than archaeal origin for brGDGTs (Sinninghe Damsté et al., 2000; Weijers et al., 2006). So far, only one brGDGT with two 13,16-dimethyl octacosanyl moieties was unambiguously detected in two species of Acidobacteria (Sinninghe Damsté et al., 2011), which hardly explains high 

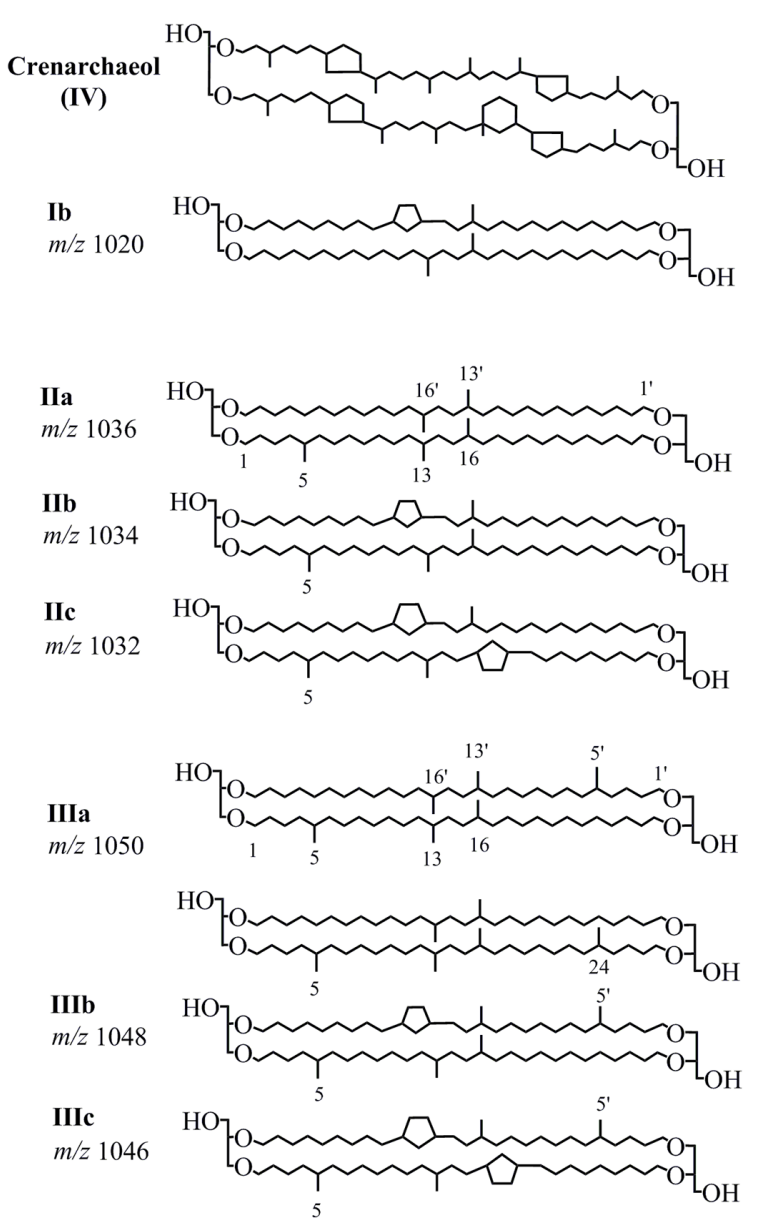

Figure 1. Chemical structures of branched GDGTs and crenarchaeol.

diversity and ubiquitous occurrence of up to 15 brGDGT isomers in environments (Weijers et al., 2007b; De Jonge et al., 2014). Therefore, other biological sources of brGDGTs, although not yet identified, are likely.

The source difference between brGDGTs and iGDGTs led researchers to develop a branched and isoprenoid tetraether (BIT) index, expressed as the relative abundance of terrestrial-derived brGDGTs to aquatic-derived Thaumarchaeotal (Hopmans et al., 2004). Subsequent studies found that the BIT index is specific to soil organic carbon because GDGTs are absent in vegetation (e.g., Walsh et al., 2008; Sparkes et al., 2015). The BIT index is generally higher than 0.9 in soils, but close to 0 in marine sediments devoid of terrestrial inputs (Weijers et al., 2006, 2014). Since its advent, the BIT index has been increasingly used to trace soil organic matter in different environments (e.g., Herfort et al., 2006; Kim et al., 2006; Blaga et al., 2011; Loomis et al., 2011; Wu et al., 2013). However, the BIT index is not just dependent on the abundance of brGDGTs, which reflects the input of soil organic matter, but also on the abundance of crenarchaeol, which is linked to marine productivity (e.g., Herfort et al., 2006; Smith et al, 2012; Fietz et al.,
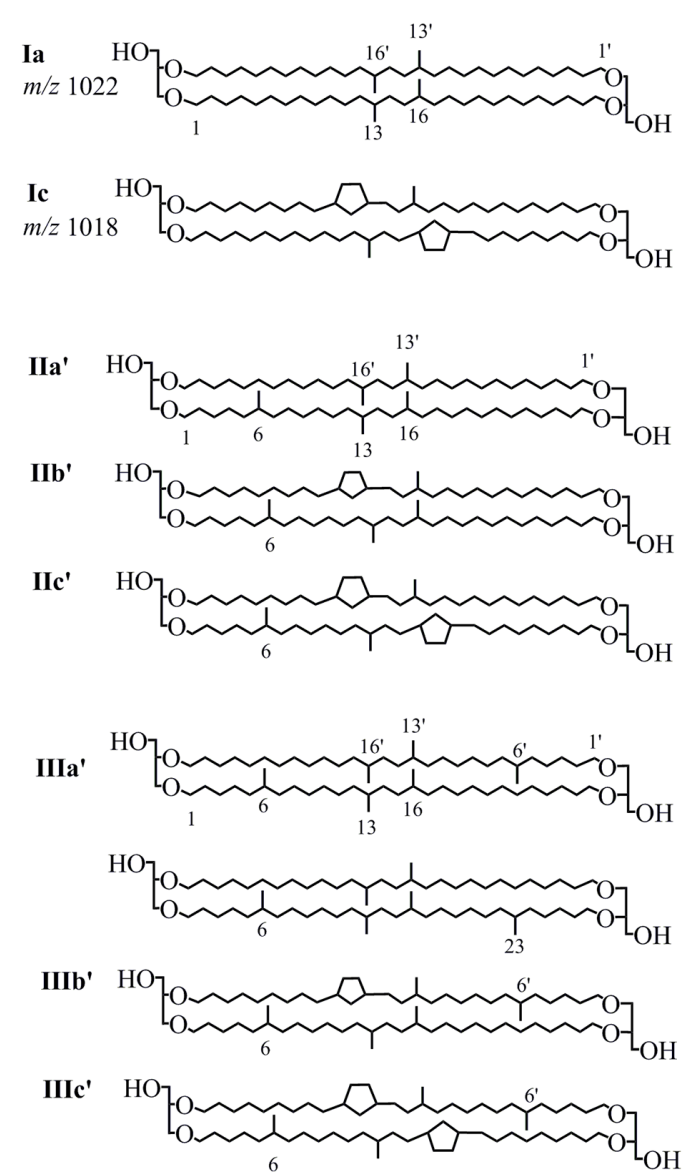

2012). Besides the BIT index, Weijers et al. (2007b) found that the number of cyclopentane moieties of brGDGTs, expressed as the cyclization of branched tetraethers (CBT), correlated negatively with soil $\mathrm{pH}$, while the number of methyl branches of brGDGTs, expressed as the methylation of branched tetraethers (MBT), was dependent on annual mean air temperature (MAT) and to a lesser extent on soil $\mathrm{pH}$. The MBT/CBT proxies were further corroborated by subsequent studies (e.g., Sinninghe Damsté et al., 2008; Peterse et al., 2012; Yang et al., 2014a). Assuming that brGDGTs preserved in marine sediments close to the Congo River outflow were derived from soils in the river catchment, Weijers et al. (2007a) reconstructed large-scale continental temperature changes in tropical Africa that span the past 25000 years by using the MBT/CBT proxy. Recently, De Jonge et al. (2013) used tandem high-performance liquid chromatography-mass spectrometry (2-D HPLC-MS) and identified a series of novel 6-methyl brGDGTs, which were previously coeluted with 5-methyl brGDGTs. This finding resulted in the redefinition and recalibration of brGDGTs' indices (e.g., De Jonge et al., 2014; Xiao et al., 2015). 
One underlying assumption of all brGDGT-based parameters is their source specificity; i.e., brGDGTs are only biosynthesized by bacteria thriving in soils and peat. Several studies, however, observed different brGDGT compositions between marine sediments and soils on adjacent lands, supporting in situ production of brGDGTs in marine environments (e.g., Peterse et al., 2009a; Zhu et al., 2011; Liu et al., 2014; Weijers et al., 2014; Zell et al., 2014), analogous to lacustrine settings (e.g., Sinninghe Damsté et al., 2009; Tierney and Russell, 2009; Tierney et al., 2012) and rivers (e.g., Zhu et al., 2011; De Jonge et al., 2015; French et al., 2015; Zell et al., 2015). Peterse et al. (2009a) compared the brGDGTs' distribution in Svalbard soils and nearby fjord sediments, and found that concentrations of brGDGTs $\left(0.01-0.20 \mu \mathrm{g} \mathrm{g}^{-1} \mathrm{dw}\right)$ in fjord sediments increased towards the open ocean and the distribution was strikingly different from that in soil. Zhu et al. (2011) examined distributions of GDGTs in surface sediments across a Yangtze Riverdominated continental margin, and found evidence for production of brGDGTs in the oxic East China Sea shelf water column and the anoxic sediments/waters of the Lower Yangtze River. At the global scale, Fietz et al. (2012) reported a significant correlation between concentrations of brGDGTs and crenarchaeol $\left(p<0.01 ; R^{2}=0.57-0.99\right)$, suggesting that a common or mixed source for brGDGTs and iGDGTs are actually commonplace in lacustrine and marine settings. More recently, Sinninghe Damsté (2016) reported tetraethers in surface sediments from 43 stations in the Berau River delta (Kalimantan, Indonesia), and this result, combined with data from other shelf systems, is coherent with the hypothesis that brGDGTs are produced in situ in shelf sediments, especially at water depth of 50-300 m.

Fluvial inputs and wind are the most important pathways for transporting terrestrial material into sea. On the continental shelf, fluvial discharge is more important than atmospheric input because brGDGTs are either below the detection level (Hopmans et al., 2004) or present at low abundance (Fietz et al., 2013; Weijers et al., 2014). In the remote ocean where no direct impact from land erosion via rivers takes place, eolian transport and in situ production are major contributors to brGDGTs. Weijers et al. (2014) found that distributions of African dust-derived brGDGTs were similar to those of soils but different from those of distal marine sediments, providing a possibility to distinguish terrestrial vs. marine brGDGTs based on molecular compositions. However, so far no robust molecular indicator is available for estimating the source of brGDGTs in marine environments. Considering this, we conduct a detailed study on GDGTs in three cores from the Bohai Sea, which are subject to the Yellow River influence to a different degree. Our purpose is to evaluate the source-discerning capability of different brGDGT parameters, from which the most sensitive parameter is selected and applied for globally distributed marine sediments and soils to test whether it is valid at the global scale. Our study supplies an important step for improving accuracy of
brGDGT-derived proxies and better understanding the marine carbon cycle and paleoenvironments.

\section{Material and methods}

\subsection{Study area and sampling}

The Bohai Sea is a semi-enclosed shallow sea in northern China, extending about $550 \mathrm{~km}$ from north to south and about $350 \mathrm{~km}$ from east to west. Its area is $77000 \mathrm{~km}^{2}$, and the mean depth is $18 \mathrm{~m}$ (Hu et al., 2009). The Bohai Strait at the eastern portion is the only passage connecting the Bohai Sea to the outer Yellow Sea. Several rivers, including the Yellow River, the second largest river in the world in terms of sediment load (Milliman and Meade, 1983), drain into the Bohai Sea with a total annual runoff of $890 \times 10^{8} \mathrm{~m}^{3}$. A gravity core $64 \mathrm{~cm}$ long $\left(\mathrm{M} 1 ; 37.52^{\circ} \mathrm{N}, 119.32^{\circ} \mathrm{E}\right)$ was collected in July 2011 , while two other cores, M3 $\left(38.66^{\circ} \mathrm{N}, 119.54^{\circ} \mathrm{E}\right.$; $53 \mathrm{~cm}$ long) and $\mathrm{M} 7\left(39.53^{\circ} \mathrm{N}, 120.46^{\circ} \mathrm{E} ; 60 \mathrm{~cm}\right.$ long), were collected in July 2013 (Fig. 2). The sites M1, M3 and M7 are located in the south, the center and the north of the Bohai Sea, respectively. The cores were transported to the lab where they were sectioned at 1 or $2 \mathrm{~cm}$ interval. The age model was established on the basis of ${ }^{210} \mathrm{~Pb}$ and ${ }^{137} \mathrm{Cs}$ activity, showing that the bottom sediments are less than 100 years old (Wu et al., 2013 and unpublished data).

\subsection{Lipid extraction and analyses}

The detailed procedures for lipid extraction and GDGT analyses have been described in previous studies (Ding et al., 2015; Xiao et al., 2015). Briefly, the homogenous freeze-dried samples were ultrasonically extracted with dichloromethane (DCM)/methanol (3:1 $v: v)$. The extracts were separated into nonpolar and polar fractions over silica gel columns. The latter fraction containing GDGTs was analyzed using an Agilent 1200 HPLC-atmospheric pressure chemical ionization-triple quadruple mass spectrometry (HPLC-APCI-MS) system. The separation of 5- and 6-methyl brGDGTs was achieved with two silica columns in sequence $(150 \mathrm{~mm} \times 2.1 \mathrm{~mm} ; 1.9 \mu \mathrm{m}$, Thermo Finnigan; USA). The quantification was achieved by comparison of the respective protonated ion peak areas of each GDGT to the internal standard ( $\mathrm{C}_{46}$ GDGT) in selected ion monitoring (SIM) mode. The protonated ions were $m / z$ 1050, 1048, 1046, 1036, 1034, 1032, 1022, 1020 and 1018 for brGDGTs, 1302, 1300, 1298, 1296 and 1292 for iGDGTs and 744 for $\mathrm{C}_{46}$ GDGT.

\subsection{Parameter calculation and statistics}

The BIT, MBT, methyl index (MI), degree of cyclization (DC) of brGDGTs and the weighted average number of cyclopentane moieties for tetramethylated brGDGTs (no. rings $s_{\text {tetra }}$ ) were calculated according to the definitions 


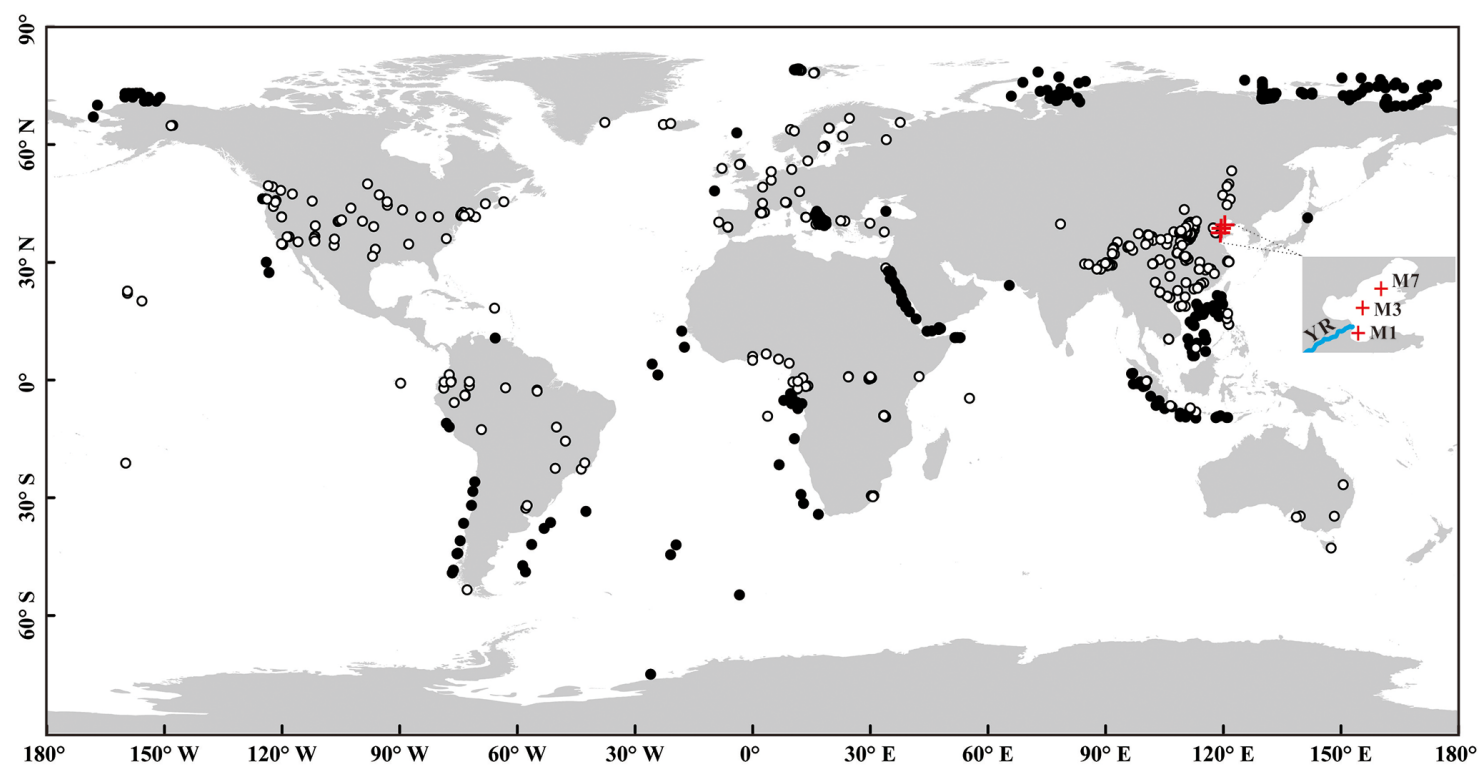

Figure 2. Location of the samples used in this study. White circles and black circles indicate the soils and marine sediments, respectively. Red crosses denote three sediment cores (M1, M3 and M7) in the Bohai Sea. YR is the Yellow River.

of Hopmans et al. (2004), Weijers et al. (2007b), Zhang et al. (2011), Sinninghe Damsté et al. (2009) and Sinninghe Damsté (2016), respectively.

$$
\begin{aligned}
\mathrm{BIT} & =\frac{\mathrm{Ia}+\mathrm{IIa}+\mathrm{IIIa}}{\mathrm{Ia}+\mathrm{IIa}+\mathrm{IIIa}+\mathrm{IV}} \\
\mathrm{MBT} & =\frac{\mathrm{Ia}+\mathrm{Ib}+\mathrm{Ic}}{\mathrm{Ia}+\mathrm{IIa}+\mathrm{III}+\mathrm{Ib}+\mathrm{IIb}+\mathrm{III} b+\mathrm{Ic}+\mathrm{IIc}+\mathrm{IIIc}} \\
\mathrm{MI} & =4 \times(\mathrm{Ia}+\mathrm{Ib}+\mathrm{Ic})+5 \times(\mathrm{IIa}+\mathrm{IIb}+\mathrm{IIb}) \\
& +6 \times(\mathrm{III} \mathrm{I}+\mathrm{III} b+\mathrm{IIIc}) \\
\mathrm{DC} & =\frac{\mathrm{Ib}+\mathrm{IIb}}{\mathrm{Ia}+\mathrm{IIa}+\mathrm{Ib}+\mathrm{IIb}} \\
\text { no. rings }_{\text {tetra }} & =\frac{\mathrm{Ib}+2 \times \mathrm{Ic}}{\mathrm{Ia}+\mathrm{Ib}+\mathrm{Ic}},
\end{aligned}
$$

where roman numbers denote relative abundance of compounds depicted in Fig. 1. In this study, we used two silica LC columns in tandem and successfully separated 5- and 6-methyl brGDGTs. However, many previous studies (e.g., Weijers et al., 2006) used one LC column, and did not separate 5- and 6-methyl brGDGTs. Considering this, we combined 5-methyl and 6-methyl brGDGT as one compound in this study; for example, IIIa denotes the total abundance of brGDGT IIIa and IIIa' in Fig. 1.

An analysis of variance (ANOVA) was conducted for different types of samples to determine whether they differ significantly from each other. The SPSS 16.0 software package (IBM, USA) was used for the statistical analysis. Squared Pearson correlation coefficients $\left(R^{2}\right)$ were reported, and the significance level is $p<0.05$.

\subsection{Data compilation of global soils and marine sediments}

The dataset in this study is composed of relative abundance of GDGTs and derived parameters from 1354 globally distributed soils and 589 marine sediments (Fig. 2 and Supplement). These sampling sites span a wide area from $75.00^{\circ} \mathrm{S}$ to $79.28^{\circ} \mathrm{N}$ and $168.08^{\circ} \mathrm{W}$ to $174.40^{\circ} \mathrm{E}$, and the water depth ranges from 1.0 to $5521 \mathrm{~m}$. The marine samples are from the South China Sea (Hu et al., 2012; Jia et al., 2012; O'Brien et al., 2014; Dong et al., 2015), the Caribbean Sea (O'Brien et al., 2014), the western equatorial Pacific Ocean (O'Brien et al., 2014), the southeast Pacific Ocean (Kaiser et al., 2015), the Chukchi and Alaskan Beaufort seas (Belicka and Harvey, 2009), the eastern Indian Ocean (Chen et al., 2014), the East Siberian Arctic Shelf (Sparkes et al., 2015), the Kara Sea (De Jonge et al., 2015, 2016), Svalbard fjord (Peterse et al., 2009a), the Red Sea (Trommer et al., 2009), the southern Adriatic Sea (Leider et al., 2010), the Columbia estuary (French et al., 2015), globally distributed distal marine sediments (Weijers et al., 2014) and the Bohai Sea (this study). Soil samples are from Svalbard (Peterse et al., 2009b), Columbia (French et al., 2015), China (Yang et al., 2013, 2014a, b; Ding et al., 2015; Xiao et al., 2015; Hu et al., 2016), California geothermal (Peterse et al., 2009b), France and Brazil (Huguet et al., 2010), western Uganda (Loomis et al., 2011), the USA (Tierney et al., 2012), Tanzania (Coffinet et al., 2014), Indonesia, Vietnam, the Philippines, China and Italy (Mueller-Niggemann et al., 2016) as well as globally distributed soils (Weijers et al., 2006; Peterse et al., 2012; De Jonge et al., 2014). 
Table 1. Parameters including brGDGTs IIIa / IIa, Ia / IIa, the BIT index, MBT, MI, DC, percentages of tetra-, penta- and hexa-methylated brGDGTs and the weighted average number of cyclopentane moieties (no. rings for tetramethylated brGDGTs) based on the GDGTs from three cores (M1, M3 and M7; see Fig. 2) in the Bohai Sea. Different letters in parentheses (a, b, c, d) represent significant difference at the level of $p<0.05$.

\begin{tabular}{lcccc}
\hline Indexes & Soil & M1 & M3 & M7 \\
\hline IIIa / IIa & $0.39 \pm 0.25(\mathrm{a})$ & $0.63 \pm 0.06(\mathrm{~b})$ & $1.16 \pm 0.12(\mathrm{c})$ & $0.93 \pm 0.07(\mathrm{~d})$ \\
Ia / IIa & $4.93 \pm 9.60(\mathrm{a})$ & $0.59 \pm 0.07(\mathrm{~b})$ & $0.81 \pm 0.06(\mathrm{~b})$ & $0.91 \pm 0.05(\mathrm{~b})$ \\
BIT & $0.75 \pm 0.22(\mathrm{a})$ & $0.50 \pm 0.19(\mathrm{~b})$ & $0.14 \pm 0.06(\mathrm{c})$ & $0.11 \pm 0.03(\mathrm{c})$ \\
MBT & $0.45 \pm 0.30(\mathrm{a})$ & $0.32 \pm 0.03(\mathrm{~b})$ & $0.33 \pm 0.01(\mathrm{~b})$ & $0.38 \pm 0.01(\mathrm{ab})$ \\
MI & $4.70 \pm 0.42(\mathrm{a})$ & $4.88 \pm 0.05(\mathrm{~b})$ & $4.91 \pm 0.03(\mathrm{~b})$ & $4.81 \pm 0.02(\mathrm{ab})$ \\
DC & $0.31 \pm 0.21(\mathrm{a})$ & $0.62 \pm 0.03(\mathrm{~b})$ & $0.79 \pm 0.03(\mathrm{c})$ & $0.82 \pm 0.02(\mathrm{c})$ \\
\%tetra & $0.45 \pm 0.30(\mathrm{a})$ & $0.32 \pm 0.03(\mathrm{~b})$ & $0.33 \pm 0.01(\mathrm{c})$ & $0.38 \pm 0.01(\mathrm{c})$ \\
\%hexa & $0.16 \pm 0.12(\mathrm{a})$ & $0.20 \pm 0.02(\mathrm{~b})$ & $0.24 \pm 0.02(\mathrm{~b})$ & $0.20 \pm 0.01(\mathrm{~b})$ \\
\%penta & $0.39 \pm 0.20(\mathrm{a})$ & $0.48 \pm 0.02(\mathrm{~b})$ & $0.44 \pm 0.02(\mathrm{~b})$ & $0.42 \pm 0.01(\mathrm{~b})$ \\
No. ringstera & $0.20 \pm 0.15(\mathrm{a})$ & $0.39 \pm 0.03(\mathrm{~b})$ & $0.47 \pm 0.02(\mathrm{c})$ & $0.47 \pm 0.02(\mathrm{c})$ \\
\hline
\end{tabular}
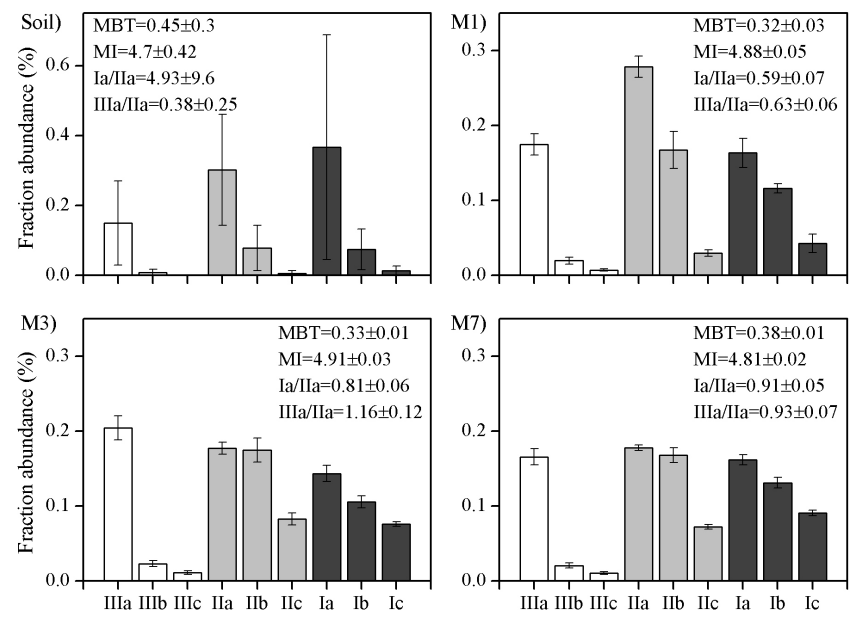

Figure 3. Averaged percentages of individual brGDGTs in soils (a), core M1 (b), M3 (c) and M7 (d). The soil data are from Yang et al. (2014a).

\section{Results and discussion}

\subsection{Distribution and source of brGDGTs in Bohai Sea}

A series of iGDGTs including crenarchaeol and brGDGTs including 5-methyl and 6-methyl isomers were detected in Bohai Sea sediments. For brGDGTs, a total of 15 compounds were identified including three tetramethylated brGDGTs (Ia, Ib and Ic), six pentamethylated brGDGTs (IIa, IIb, IIc, IIa', IIb' and IIc') and six hexamethylated brGDGTs (IIIa, IIIb, IIIc, IIIa', IIIl' and IIIc'). In order to evaluate provenances of brGDGTs, we calculated various parameters including the BIT index, percentages of tetra-, pentaand hexa-methylated brGDGTs, no. rings for tetramethylated brGDGTs, DC, MI, MBT, brGDGTs IIIa / IIa and Ia / IIa (Table 1). The values of the BIT index ranged from 0.27 to 0.76 in the core M1, which are much higher than that in the core M3 (0.04-0.25) and the core M7 (0.04-0.18). Such a difference is not surprising because the site M1 is closest to the Yellow River outflow, and it receives more terrestrial organic carbon than the other (Fig. 2). However, the BIT index itself has no ability to determine the source of brGDGTs (terrestrial vs. aquatic) because brGDGTs and crenarchaeol used in this index are thought to be specific to soil organic carbon and marine organic carbon, respectively (Hopmans et al., 2004), although crenarchaeol is also present in soils at low abundance (Weijers et al., 2006). For individual brGDGTs, the core M1 is characterized by significantly higher percentage of brGDGT IIa $(28 \pm 1 \%)$ than the core M2 $(18 \pm 1 \%)$ and the core M3 (18 $\pm 0 \%$; Fig. 3$)$. We performed ANOVA for a variety of brGDGTs' parameters. All results except from MI show a significant difference between Chinese soils and Bohai Sea sediments. The IIIa / IIa ratio is the most sensitive parameter which can completely separate the samples into four groups: Chinese soils $(0.39 \pm 0.25$; mean \pm standard deviation; same hereafter), M1 sediments $(0.63 \pm 0.06), \mathrm{M} 3$ sediments $(1.16 \pm 0.12)$ and $\mathrm{M} 7$ sediments $(0.93 \pm 0.07)$.

Three factors may account for the occurrence of higher IIIa / IIa ratio in the Bohai Sea sediments than Chinese soils: selective degradation during land to sea transport, admixture of river produced brGDGTs and in situ production of brGDGTs in sea. Huguet et al. $(2008,2009)$ reported that iGDGTs (i.e., crenarchaeol) were degraded at a rate 2 -fold higher than soil-derived brGDGTs under long-term oxygen exposure in the Madeira Abyssal Plain, leading to increase of the BIT index. Such selective degradation, however, cannot explain the significantly different IIIa / IIa ratios between the Chinese soils and Bohai Sea sediments because unlike crenarchaeol, both IIIa and IIa belong to brGDGTs with similar chemical structures, and thus have similar degradation rates. In situ production of brGDGTs in rivers is a widespread phenomenon, and can change brGDGTs' composition in sea when they are transported there (e.g., Zhu 

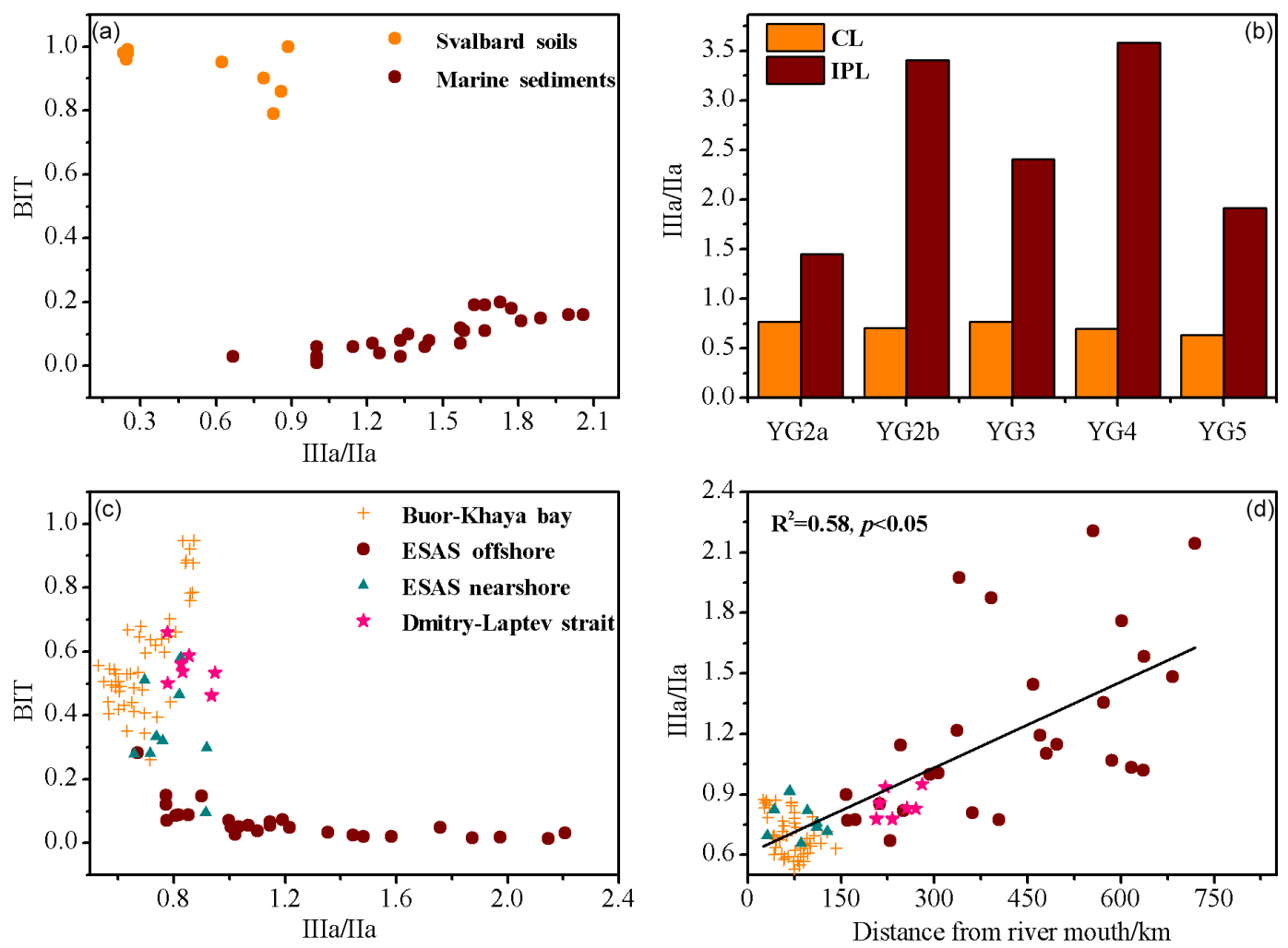

Figure 4. (a) The relationship between brGDGT IIIa / IIa ratio and the BIT index of samples from Peterse et al. (2009a); (b) histograms of brGDGT IIIa / IIa ratio of the core lipids (CLs) and intact polar lipids (IPLs) in samples from De Jonge et al. (2015); (c) the relationship between brGDGT IIIa / IIa ratio and the BIT index in samples from Sparkes et al. (2015); (d) the relationship between brGDGT IIIa / IIa ratio and distance from the river mouth in samples from Sparkes et al. (2015).

et al., 2011; De Jonge et al., 2015; Zell et al., 2015). However, the study along the lower Yellow River-estuary-coast transect suggests that brGDGTs in surface sediments are primarily of land origin (Wu et al., 2014). In our study, the site M1 is adjacent to the Yellow River mouth, and receives the largest amount of terrestrial organic matter, causing lower IIIa / IIa values $(0.63 \pm 0.06)$. In contrast, the site M3 located in central Bohai Sea comprises the least amount of terrestrial organic matter, resulting in higher IIIa / IIa values $(1.16 \pm 0.12)$. The intermediate IIIa / IIa values at the site M7 $(0.93 \pm 0.07)$ is attributed to moderate land erosion nearby the northern Bohai Sea (Fig. 2). These GDGTs' results, consistent with other terrestrial biomarkers such as $\mathrm{C}_{29}$ and $\mathrm{C}_{31} n$ alkanes and $\mathrm{C}_{29}$ sterol (data not showed here), suggest that the higher IIIa/IIa values in the Bohai Sea sediments compared to Chinese soils $(0.39 \pm 0.25)$ are most likely caused by in situ production of brGDGTs.

\subsection{Regional and global validation of brGDGT IIIa / IIa}

To test whether the IIIa / IIa ratio is valid in other environments, we apply it to the dataset for Svalbard (Peterse et al., 2009a), the Yenisei River outflow (De Jonge et al., 2015) and the East Siberian Arctic Shelf (Sparkes et al., 2015). Similar to Bohai Sea in this study, the compounds brGDGT IIa and IIIa are also ubiquitously present in these environments. By comparing the compositions of brGDGTs in Svalbard soils and nearby fjord sediments, Peterse et al. (2009a) indicated that sedimentary organic matter in fjords was predominantly from marine origin. A plot of BIT vs. IIIa / IIa (Fig. 4a) clearly grouped the samples into two groups, which correspond to soils $(>0.75$ for BIT and $<1.0$ for IIIa / IIa) and marine sediments ( $<0.3$ for BIT and $>1.0$ for IIIa $/$ IIa). Another line of evidence is from De Jonge et al. (2015) who examined brGDGTs in core lipids (CLs) and intact polar lipids (IPLs) in the Yenisei River outflow. As the IPLs are rapidly degraded in the environment, they can be used to trace living or recently living material, while the CLs are generated via degradation of the IPLs after cell death (White et al., 1979; Lipp et al., 2008). The compilation of brGDGTs' abundance from De Jonge et al. (2015) shows significant difference of the IIIa / IIa ratio between the IPL fractions ( $>1.0)$ and CL fractions $(<0.8$; Fig. $4 b)$. Such disparity supports the hypothesis that brGDGTs produced in marine environments have higher IIIa / IIa values because labile intact polar brGDGTs are mainly produced in situ, whereas recalcitrant core brGDGTs are composed of more allochthonous terres- 


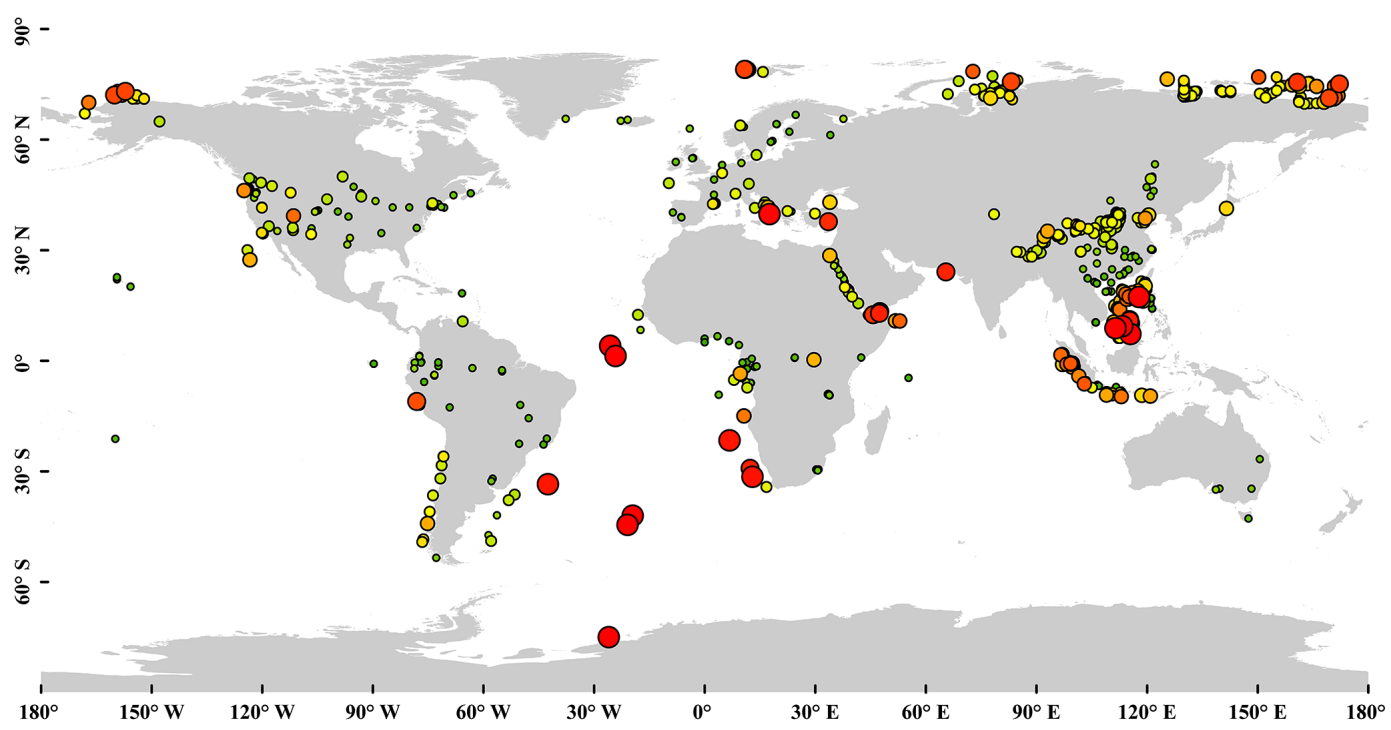

Figure 5. Global distribution pattern of brGDGT IIIa / IIa ratio in soils and marine sediments.

trial components. Sparkes et al. (2015) examined brGDGTs in surface sediments across the East Siberian Arctic Shelf (ESAS) including the Dmitry Laptev Strait, Buor-Khaya Bay, ESAS nearshore and ESAS offshore. The plot of BIT vs. IIIa / IIa again results in two groups, one group with lower BIT values $(<0.3)$ and higher IIIa / IIa values $(0.8-$ 2.3), mainly from ESAS offshore, and another group with higher BIT values (0.3-1.0) and lower IIIa / IIa values (0.40.9), from the Dmitry-Laptev Strait, Buor-Khaya Bay and ESAS nearshore (Fig. 4c). A strong linear correlation was observed between the IIIa / IIa ratio and the distance from the river mouth $\left(R^{2}=0.58 ; p<0.05\right.$; Fig. $\left.4 \mathrm{~d}\right)$, in accordance with the data of the BIT index and $\delta^{13} \mathrm{C}_{\text {org }}$ (Sparkes et al., 2015). All lines of evidence support the concept that marine-derived brGDGTs have higher IIIa / IIa values than terrestrial-derived brGDGTs.

We further extend the dataset for global scale (Fig. 5), showing that the IIIa / IIa ratio is still significantly higher in marine sediments than soils $(p<0.01)$. An exception was observed for Red Sea sediments, which have unusually low IIIa / IIa values $(0.39 \pm 0.21)$ compared to other marine sediments $(>0.87)$. The Red Sea has a restricted connection to the Indian Ocean via the Bab el Mandeb Strait. This, combined with high insolation, low precipitation and strong winds results in surface water salinity up to 41 PSU in the south and 36 PSU in the north of the Red Sea (Sofianos et al., 2002). Under such an extreme environment, distinct microbial populations may develop and produce GDGTs different from those in other marine settings (see Trommer et al., 2009 for details).

Overall, the global distribution of IIIa / IIa shows the highest values in many deep sea sediments (2.6-5.1), the lowest values in soils $(<1.0)$, and intermediate values in sediments

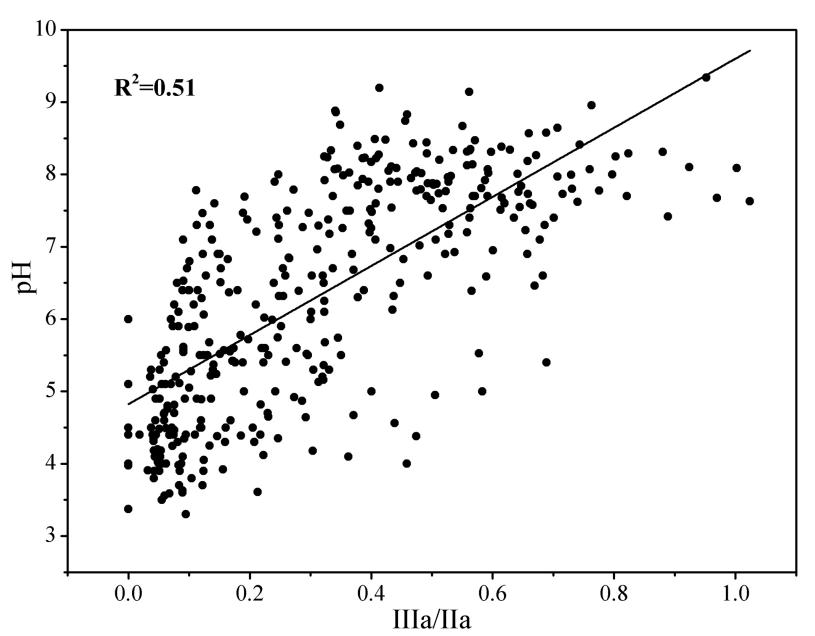

Figure 6. A plot showing a positive correlation between soil $\mathrm{pH}$ and IIIa / IIa. The data are from Peterse et al. (2012) and this study.

from bays, coastal areas or marginal seas (0.87-2.62; Fig. 5). These results are consistent with our data from the Bohai Sea, and confirm that the IIIa / IIa ratio is a useful proxy for tracing the source of brGDGTs in marine sediments at regional and global scales.

Why do marine sediments generally have higher IIIa / IIa values than soils? It has been reported that the relative of methyl groups positively correlates with soil $\mathrm{pH}$ and negatively correlates with MAT (Weijers et al., 2007b; Peterse et al., 2012). The IIIa / IIa ratio is actually an abundance ratio of hexamethylated to pentamethylated brGDGT, and thus is also affected by ambient temperature and $\mathrm{pH}$. Unlike iGDGTs, which are well known to be mainly produced by Thaumarchaeota (Sinninghe Damsté et al., 2002; Schouten 


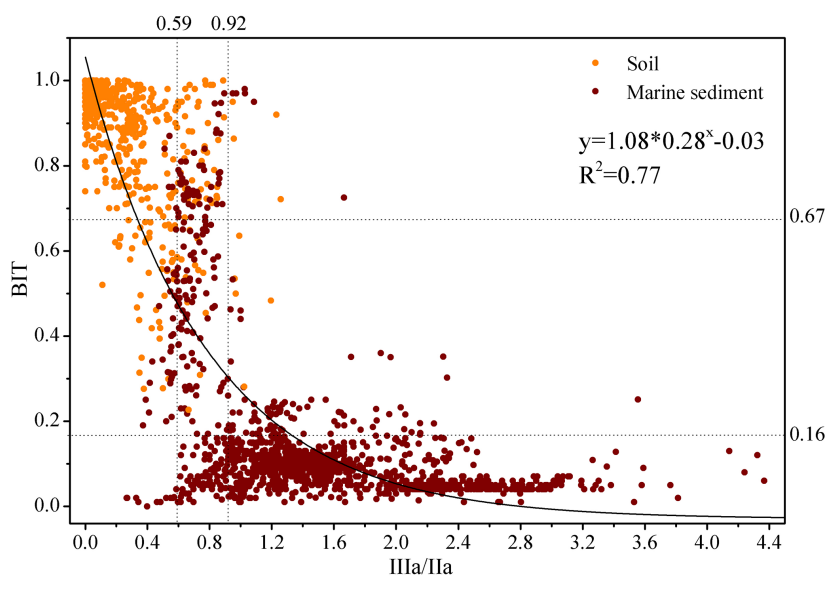

Figure 7. Relationship between the IIIa / IIa ratio and the BIT index of globally distributed samples: soils (orange circle) and marine sediments (red circle). Dashed lines represent lower or upper threshold values for $90 \%$ of soils/sediments.

et al., 2008), the marine source of brGDGTs remains elusive. Here, we assume that marine organisms producing brGDGTs respond to ambient temperature in the same way as the brGDGTs producing soil bacteria, i.e., a negative correlation between relative number of methyl group of brGDGTs and ambient temperature. Because a large temperature gradient exists from surface to bottom water in the ocean, we need to consider the location where brGDGTs are produced. If brGDGTs in marine environments are predominantly produced in the euphotic zone, we would not observe a significant difference for the IIIa / IIa ratio between land and sea because both soils and marine sediments are globally distributed, leading to no systematic difference between soil temperature and sea surface temperature. Alternatively, if brGDGTs in marine sediments are partially derived from deep-water dwelling or benthic organisms, cold deep water (generally $1-2^{\circ} \mathrm{C}$ ) would cause higher IIIa / IIa values in marine sediments, as we observed in this study. However, to the best of our knowledge, there is no study reporting in situ production of brGDGTs throughout the water column in ocean. Recent studies (Taylor et al., 2013; Kim et al., 2015) have suggested that Thaumarchaeota are thriving in the deeper, bathypelagic water column $(>1000 \mathrm{~m}$ water depth) biosynthesized iGDGTs with different compositions to surface-dwelling Thaumarchaeota, and thereby alter signals of $\mathrm{TEX}_{86}$ in sediments. Besides temperature, $\mathrm{pH}$ can also alter compositions of brGDGTs (Weijers et al., 2007). Based on global soil data, the IIIa / IIa ratio shows a strong positive correlation with soil $\mathrm{pH}\left(R^{2}=0.51\right.$; Fig. 6). In our study, the majority of soils are acidic or neutral $(\mathrm{pH}<7.3)$, and only $8 \%$ of soil samples mainly from semi-arid and arid regions have a pH of $>8.0$ (e.g., Yang et al., 2014a). In contrast, seawater is constantly alkaline, with a mean $\mathrm{pH}$ of 8.2. With this systematic difference, bacteria living in soils tend
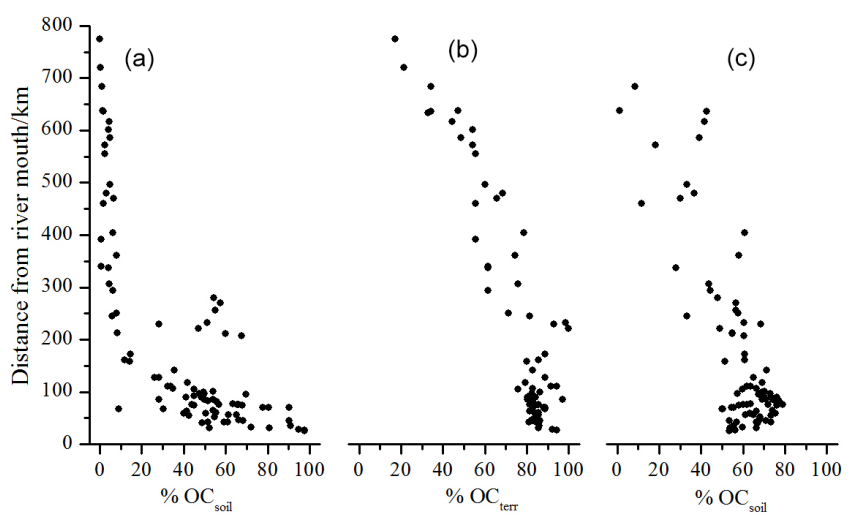

Figure 8. Percentage of soil organic carbon $\left(\% \mathrm{OC}_{\text {soil }}\right)$ or terrestrial organic carbon $\left(\% \mathrm{OC}_{\text {terr }}\right)$ based on a binary mixing model of BIT (a), $\delta^{13} \mathrm{C}_{\text {org }}$ (b) and IIIa / IIa (c) for the East Siberian Arctic Shelf (Sparkes et al., 2015).

to produce higher proportions of brGDGT IIa, whereas unknown marine organisms tend to biosynthesize higher proportions of brGDGT IIIa if they respond to ambient $\mathrm{pH}$ in a similar way as soil bacteria in terms of biosynthesis of brGDGTs. It should be pointed out that unlike fairly stable $\mathrm{pH}$ of overlying seawater, the $\mathrm{pH}$ of porewaters in marine sediments can vary significantly, which may influence compositions of brGDGTs. Nevertheless, at the current stage, the occurrence of higher IIIa / IIa values in marine sediments is most likely attributed to the relative higher $\mathrm{pH}$ and lower water temperature. Further studies are needed to disentangle the relative importance of these two factors.

\subsection{Implication of IIIa / IIa on other brGDGT proxies}

Because brGDGTs can be produced in marine settings, they are no longer specific to soil organic matter, which inevitably affects brGDGT proxies (e.g., BIT, MBT/CBT). The plot of BIT vs. IIIa / IIa on the basis of the global dataset shows that the IIIa / IIa ratio has a value of $<0.59$ for $90 \%$ of soil samples and $>0.92$ for $90 \%$ of marine sediments (Fig. 7). Considering this fact, we propose that the IIIa / IIa ratio of $<0.59$ and $>0.92$ represents terrestrial (or soil) and marine endmembers, respectively. The BIT index has a value of $>0.67$ for $90 \%$ of soils and $<0.16$ for $90 \%$ of marine sediments (Fig. 7). Overall, the BIT index decreased with increasing IIIa / IIa values $\left(\mathrm{BIT}=1.08 \times 0.28^{\text {IIIa }}-0.03 ; R^{2}=0.77\right.$; Fig. 7), suggesting that both the IIIa / IIa and BIT are useful indexes for assessing soil organic carbon in marine settings. However, when the BIT index has an intermediate value (i.e., 0.16 to 0.67 ), it is not valid to determine the provenance of brGDGTs. For example, several marine samples with BIT values of $\sim 0.35$ show a large range of IIIa / IIa (0.4 to 2.4; Fig. 7), suggesting that the source of brGDGTs can vary case by case. In this situation, the measurement of the IIIa / IIa ratio is strongly recommended. 
The different IIIa / IIa values between land and marine endmembers may provide an approach to quantify the contribution of soil organic carbon in marine sediments. Similar to the BIT index, we used a binary mixing model to calculate percentage of soil organic carbon $\left(\% \mathrm{OC}_{\text {soil }}\right)$ as follows:

$\% \mathrm{OC}_{\text {soil }}=\left[\frac{[\mathrm{IIIa} / \mathrm{IIa}]_{\text {sample }}-[\mathrm{IIIa} / \mathrm{IIa}]_{\text {marine }}}{[\mathrm{IIIa} / \mathrm{IIa}]_{\text {soil }}-[\mathrm{IIIa} / \mathrm{IIa}]_{\text {marine }}}\right] \times 100$,

where [IIIa / IIa $]_{\text {sample, }}$ [IIIa / IIa $]_{\text {soil }}$ and [IIIa / IIa $]_{\text {marine }}$ are the abundance ratio of brGDGT IIIa / IIa for samples, soils and marine sediments devoid of terrestrial influences, respectively.

We applied this binary mixing model to the East Siberian Arctic Shelf because the data of BIT, $\delta^{13} \mathrm{C}_{\text {org }}$ and distance from the river mouth are all available (Sparkes et al., 2015). With the distance from the river mouth increasing from 25 to $>700 \mathrm{~km}$, the BIT, IIIa / IIa and $\delta^{13} \mathrm{C}_{\text {org }}$ change from 0.95 to $0,0.53$ to 2.21 and -27.4 to $-21.2 \%$, respectively, reflecting the spatial variability of sedimentary organic carbon sources. For the BIT index, we used 0.97 and 0.01 as terrestrial and marine endmember values based on previous studies for Arctic surrounding regions (De Jonge et al., 2014; Peterse et al., 2014), which are similar to global average values (Hopmans et al., 2004). For $\delta^{13} \mathrm{C}_{\text {org }}$, we chose -27 and $-20 \%$ as $\mathrm{C} 3$ terrestrial and marine organic carbon endmembers (Meyers, 1997). For the IIIa / IIa ratio, we used a global average value of marine sediments (1.6) and soils (0.24), respectively, based on this study. By applying these endmember values in Eq. (6), we calculated the percentage of soil organic carbon $\left(\% \mathrm{OC}_{\text {soil }}\right)$. We removed a few data points if their calculated $\% \mathrm{OC}_{\text {soil }}$ values were greater than 100 or below $0 \%$. It should be noted that the endmember value will affect quantitative results, but does not change a general trend of $\% \mathrm{OC}_{\text {soil }}$. The results based on all three parameters show a decreasing trend seawards (Fig. 8). However, the $\% \mathrm{OC}_{\text {soil }}$ based on $\delta^{13} \mathrm{C}_{\text {org }}$ is the highest $(75 \pm 18 \%)$, followed by that from the IIIa / IIa ratio $(58 \pm 15 \%)$ and then that from the BIT index $(43 \pm 27 \%)$. This difference has been explained by the fact that $\delta^{13} \mathrm{C}_{\text {org }}$ is a bulk proxy for marine vs. terrestrial influence of sedimentary organic carbon (SOC), whereas the BIT index is for a portion of the bulk SOC, i.e., soil OC (Walsh et al., 2008) or fluvial OC (Sparkes et al., 2015). For the estimated $\% \mathrm{OC}_{\text {soil }}, \delta^{13} \mathrm{C}_{\text {org }}$ presents a stronger positive correlation with the IIIa / IIa ratio $\left(R^{2}=0.49\right)$ than the BIT index $\left(R^{2}=0.45\right)$, suggesting that the IIIa / IIa ratio may serve as a better proxy for quantifying soil organic carbon than the BIT index because it is less affected by selective degradation of branched vs. isoprenoid GDGTs and high production of crenarchaea in marine environments (Smith et al., 2012).

\section{Conclusions}

Our investigation in brGDGTs in three Bohai Sea cores and globally distributed soils and marine sediments shows that the brGDGTs IIIa / IIa ratio is lower than 0.59 in $90 \%$ of soils, but higher than 0.92 in $90 \%$ of marine sediments devoid of significant terrestrial inputs, supporting the hypothesis that the IIIa / IIa is a sensitive proxy for assessing soil vs. marine-derived brGDGTs at regional and global scales. The in situ production of brGDGTs in marine environments is a ubiquitous phenomenon, which is particularly important for those marine sediments with low BIT index $(<0.16)$ where brGDGTs are primarily of marine origin. A systemic difference of the IIIa / IIa value between soils and marine sediments reflects an effect of $\mathrm{pH}$ or the combined effect of $\mathrm{pH}$ and temperature on the biosynthesis of brGDGTs by source organisms. Given these facts, we recommend calculating the IIIa / IIa ratio before estimating the organic carbon source, paleosoil $\mathrm{pH}$ and MAT based on the BIT and MBT/CBT proxies. We also note a relatively large scatter of the IIIa / IIa ratio within both terrestrial and marine realms, and recently reported different environmental responses of 5-methyl vs. 6-methyl brGDGTs (e.g., De Jonge et al., 2014, 2016; Xiao et al., 2015). As a result, the separation of these two types of isomers is needed in future studies in order to develop more accurate brGDGTs-based proxies.

\section{The Supplement related to this article is available online at doi:10.5194/bg-13-5883-2016-supplement.}

Acknowledgements. The work was financially supported by the National Science Foundation of China (41476062). We are grateful to X. Dang for GDGT analyses. G. Jia, J. Hu, A. Leider, G. Mollenhauer, G. Trommer and R. Smith are thanked for kindly supplying GDGT data. Ding He and two anonymous reviewers are thanked for constructive comments.

Edited by: J. Middelburg

Reviewed by: two anonymous referees

\section{References}

Belicka, L. L. and Harvey, H. R.: The sequestration of terrestrial organic carbon in Arctic Ocean sediments: A comparison of methods and implications for regional carbon budgets, Geochim. Cosmochim. Ac., 73, 6231-6248, 2009.

Blaga, C. I., Reichart, G. J., Vissers, E. W., Lotter, A. F., Anselmetti, F. S., and Damste, J. S. S.: Seasonal changes in glycerol dialkyl glycerol tetraether concentrations and fluxes in a perialpine lake: Implications for the use of the TEX 86 and BIT proxies, Geochim. Cosmochim. Ac., 75, 6416-6428, 2011.

Chen, W., Mohtadi, M., Schefuß, E., and Mollenhauer, G.: Organicgeochemical proxies of sea surface temperature in surface sediments of the tropical eastern Indian Ocean, Deep-Sea Res. Pt. I, 88, 17-29, 2014. 
Coffinet, S., Huguet, A., Williamson, D., Fosse, C., and Derenne, S.: Potential of GDGTs as a temperature proxy along an altitudinal transect at Mount Rungwe (Tanzania), Org. Geochem., 68, 8289, 2014.

De Jonge, C., Hopmans, E. C., Stadnitskaia, A., Rijpstra, W. I. C., Hofland, R., Tegelaar, E., and Sinninghe Damsté, J. S.: Identification of novel penta- and hexamethylated branched glycerol dialkyl glycerol tetraethers in peat using HPLC-MS2, GC-MS and GC-SMB-MS, Org. Geochem., 54, 78-82, 2013.

De Jonge, C., Hopmans, E. C., Zell, C. I., Kim, J.-H., Schouten, S., and Sinninghe Damsté, J. S.: Occurrence and abundance of 6-methyl branched glycerol dialkyl glycerol tetraethers in soils: Implications for palaeoclimate reconstruction, Geochim. Cosmochim. Ac., 141, 97-112, 2014.

De Jonge, C., Stadnitskaia, A., Hopmans, E. C., Cherkashov, G., Fedotov, A., Streletskaya, I. D., Vasiliev, A. A., and Sinninghe Damsté, J. S.: Drastic changes in the distribution of branched tetraether lipids in suspended matter and sediments from the Yenisei River and Kara Sea (Siberia): Implications for the use of brGDGT-based proxies in coastal marine sediments, Geochim. Cosmochim. Ac., 165, 200-225, 2015.

De Jonge, C., Stadnitskaia, A., Cherkashov, G., and Sinninghe Damsté, J. S.: Branched glycerol dialkyl glycerol tetraethers and crenarchaeol record post-glacial sea level rise and shift in source of terrigenous brGDGTs in the Kara Sea (Arctic Ocean), Org. Geochem., 92, 42-54, 2016.

Ding, S., Xu, Y., Wang, Y., He, Y., Hou, J., Chen, L., and He, J.S.: Distribution of branched glycerol dialkyl glycerol tetraethers in surface soils of the Qinghai-Tibetan Plateau: implications of brGDGTs-based proxies in cold and dry regions, Biogeosciences, 12, 3141-3151, doi:10.5194/bg-12-3141-2015, 2015.

Dong, L., Li, Q., Li, L., and Zhang, C. L.: Glacial-interglacial contrast in MBT/CBT proxies in the South China Sea: Implications for marine production of branched GDGTs and continental teleconnection, Org. Geochem., 79, 74-82, 2015.

Fietz, S., Huguet, C., Bendle, J., Escala, M., Gallacher, C., Herfort, L., Jamieson, R., Martínez-Garcia, A., McClymont, E. L., Peck, V. L., Prahl, F. G., Rossi, S., Rueda, G., Sanson-Barrera, A., and Rosell-Melé, A.: Co-variation of crenarchaeol and branched GDGTs in globally-distributed marine and freshwater sedimentary archives, Global Planet. Change, 92, 275-285, 2012.

Fietz, S., Prahl, F. G., Moraleda, N., and Rosell-Melé, A.: Eolian transport of glycerol dialkyl glycerol tetraethers (GDGTs) off northwest Africa, Org. Geochem., 64, 112-118, 2013.

French, D. W., Huguet, C., Turich, C., Wakeham, S. G., Carlson, L. T., and Ingalls, A. E.: Spatial distributions of core and intact glycerol dialkyl glycerol tetraethers (GDGTs) in the Columbia River Basin and Willapa Bay, Washington: Insights into origin and implications for the BIT index, Org. Geochem., 88, 91-112, 2015.

Herfort, L., Schouten, S., Boon, J. P., Woltering, M., Baas, M., Weijers, J. W. H., and Damsté, J. S. S.: Characterization of transport and deposition of terrestrial organic matter in the southern North Sea using the BIT index, Limnol. Oceanogr., 51, 21962205, 2006.

Hopmans, E. C., Weijers, J. W. H., Schefuss, E., Herfort, L., Damste, J. S. S., and Schouten, S.: A novel proxy for terrestrial organic matter in sediments based on branched and isoprenoid tetraether lipids, Earth Planet. Sc. Lett., 224, 107-116, 2004.
Hu, J., Meyers, P. A., Chen, G., Peng, P. A., and Yang, Q.: Archaeal and bacterial glycerol dialkyl glycerol tetraethers in sediments from the Eastern Lau Spreading Center, South Pacific Ocean, Org. Geochem., 43, 162-167, 2012.

Hu, J., Zhou, H., Peng, P. A., and Spiro, B.: Seasonal variability in concentrations and fluxes of glycerol dialkyl glycerol tetraethers in Huguangyan Maar Lake, SE China: Implications for the applicability of the MBT-CBT paleotemperature proxy in lacustrine settings, Chem. Geol., 420, 200-212, 2016.

Hu, L., Guo, Z., Feng, J., Yang, Z., and Fang, M.: Distributions and sources of bulk organic matter and aliphatic hydrocarbons in surface sediments of the Bohai Sea, China, Mar. Chem., 113, 197-211, 2009.

Huguet, A., Fosse, C., Metzger, P., Fritsch, E., and Derenne, S.: Occurrence and distribution of extractable glycerol dialkyl glycerol tetraethers in podzols, Org. Geochem., 41, 291-301, 2010.

Huguet, C., de Lange, G. J., Gustafsson, Ö., Middelburg, J. J., Sinninghe Damsté, J. S., and Schouten, S.: Selective preservation of soil organic matter in oxidized marine sediments (Madeira Abyssal Plain), Geochim. Cosmochim. Ac., 72, 6061-6068, 2008.

Huguet, C., Kim, J.-H., de Lange, G. J., Sinninghe Damsté, J. S., and Schouten, S.: Effects of long term oxic degradation on the , TEX $_{86}$ and BIT organic proxies, Org. Geochem., 40, 1188-1194, 2009.

Jia, G., Zhang, J., Chen, J., Peng, P. A., and Zhang, C. L.: Archaeal tetraether lipids record subsurface water temperature in the South China Sea, Org. Geochem., 50, 68-77, 2012.

Kaiser, J., Schouten, S., Kilian, R., Arz, H. W., Lamy, F., and Sinninghe Damsté, J. S.: Isoprenoid and branched GDGT-based proxies for surface sediments from marine, fjord and lake environments in Chile, Org. Geochem., 89, 117-127, 2015.

Kim, J. H., Schouten, S., Buscail, R., Ludwig, W., Bonnin, J., Sinninghe Damsté, J. S., and Bourrin, F.: Origin and distribution of terrestrial organic matter in the NW Mediterranean (Gulf of Lions): Exploring the newly developed BIT index, Geochem. Geophy. Geosy., 7, 220-222, 2006.

Kim, J. H., Meer, J. V. D., Schouten, S., Helmke, P., Willmott, V., Sangiorgi, F., Koç, N., Hopmans, E. C., and Damsté, J. S. S.: New indices and calibrations derived from the distribution of crenarchaeal isoprenoid tetraether lipids: Implications for past sea surface temperature reconstructions, Geochim. Cosmochim. Ac., 74, 4639-4654, 2010.

Kim, J.-H., Schouten, S., Rodrigo-Gámiz, M., Rampen, S., Marino, G., Huguet, C., Helmke, P., Buscail, R., Hopmans, E. C., Pross, J., Sangiorgi, F., Middelburg, J. B. M., and Sinninghe Damsté, J. S.: Influence of deep-water derived isoprenoid tetraether lipids on the paleothermometer in the Mediterranean Sea, Geochim. Cosmochim. Ac., 150, 125-141, 2015.

Leider, A., Hinrichs, K. U., Mollenhauer, G., and Versteegh, G. J. M.: Core-top calibration of the lipid-based UK'37 and TEX 86 temperature proxies on the southern Italian shelf (SW Adriatic Sea, Gulf of Taranto), Earth Planet. Sc. Lett., 300, 112-124, 2010.

Lincoln, S. A., Wai, B., Eppley, J. M., Church, M. J., Summons, R. E., and Delong, E. F.: Planktonic Euryarchaeota are a significant source of archaeal tetraether lipids in the ocean, P. Natl. Acad. Sci. USA, 111, 9858-9863, 2014. 
Lipp, J. S., Morono, Y., Inagaki, F., and Hinrichs, K. U.: Significant contribution of Archaea to extant biomass in marine subsurface sediments, Nature, 454, 991-994, 2008.

Liu, X.-L., Zhu, C., Wakeham, S. G., and Hinrichs, K.-U.: In situ production of branched glycerol dialkyl glycerol tetraethers in anoxic marine water columns, Mar. Chem., 166, 1-8, 2014.

Loomis, S. E., Russell, J. M., and Damsté, J. S. S.: Distributions of branched GDGTs in soils and lake sediments from western Uganda: Implications for a lacustrine paleothermometer, Org. Geochem., 42, 739-751, 2011.

Meyers, P. A.: Organic geochemical proxies of paleoceanographic, paleolimnologic, and paleoclimatic processes, Org. Geochem., 27, 213-250, 1997.

Milliman, J. D. and Meade, R. H.: World-wide delivery of river sediment to the oceans, J. Geol., 91, 1-21, 1983.

Mueller-Niggemann, C., Utami, S. R., Marxen, A., Mangelsdorf, K., Bauersachs, T., and Schwark, L.: Distribution of tetraether lipids in agricultural soils - differentiation between paddy and upland management, Biogeosciences, 13, 1647-1666, doi:10.5194/bg-13-1647-2016, 2016.

O’Brien, C. L., Foster, G. L., Martínez-Botí, M. A., Abell, R., Rae, J. W. B., and Pancost, R. D.: High sea surface temperatures in tropical warm pools during the Pliocene, Nat. Geosci., 7, 606611,2014

Peterse, F., Kim, J.-H., Schouten, S., Kristensen, D. K., Koç, N., and Sinninghe Damsté, J. S.: Constraints on the application of the MBT/CBT palaeothermometer at high latitude environments (Svalbard, Norway), Org. Geochem., 40, 692-699, 2009a.

Peterse, F., Schouten, S., van der Meer, J., van der Meer, M. T. J., and Sinninghe Damsté, J. S.: Distribution of branched tetraether lipids in geothermally heated soils: Implications for the MBT/CBT temperature proxy, Org. Geochem., 40, 201-205, 2009b.

Peterse, F., van der Meer, J., Schouten, S., Weijers, J. W. H., Fierer, N., Jackson, R. B., Kim, J.-H., and Sinninghe Damsté, J. S.: Revised calibration of the MBT-CBT paleotemperature proxy based on branched tetraether membrane lipids in surface soils, Geochim. Cosmochim. Ac., 96, 215-229, 2012.

Peterse, F., Vonk, J. E., Holmes, R. M., Giosan, L., Zimov, N., and Eglinton, T. I.: Branched glycerol dialkyl glycerol tetraethers in Arctic lake sediments: Sources and implications for paleothermometry at high latitudes, J. Geophys. Res.-Biogeo., 119, 17381754, 2014.

Schouten, S., Hopmans, E. C., Schefuß, E., and Sinninghe Damsté, J. S.: Distributional variations in marine crenarchaeotal membrane lipids: a new tool for reconstructing ancient sea water temperatures?, Earth Planet. Sc. Lett., 204, 265-274, 2002.

Schouten, S., Hopmans, E. C., Baas, M., Boumann, H., Standfest, S., Konneke, M., Stahl, D. A., and Sinninghe Damste, J. S.: Intact membrane lipids of "Candidatus Nitrosopumilus maritimus", a cultivated representative of the cosmopolitan mesophilic group I Crenarchaeota, Appl. Environ. Microbiol., 74, 2433-2440, 2008.

Schouten, S., Hopmans, E. C., and Sinninghe Damsté, J. S.: The organic geochemistry of glycerol dialkyl glycerol tetraether lipids: A review, Org. Geochem., 54, 19-61, 2013.

Sinninghe Damsté, J. S.: Spatial heterogeneity of sources of branched tetraethers in shelf systems: The geochemistry of tetraethers in the Berau River delta (Kalimantan, Indonesia), Geochim. Cosmochim. Ac., 186, 13-31, 2016.
Sinninghe Damsté, J. S., Hopmans, E. C., Pancost, R. D., Schouten, S., and Geenevasen, J. A. J.: Newly discovered non-isoprenoid glycerol dialkyl glycerol tetraether lipids in sediments, Chem. Commun., 17, 1683-1684, 2000.

Sinninghe Damsté, J. S., Schouten, S., Hopmans, E. C., van Duin, A. C. T., and Geenevasen, J. A. J.: Crenarchaeol: the characteristic core glycerol dibiphytanyl glycerol tetraether membrane lipid of cosmopolitan pelagic crenarchaeota, J. Lipid Res., 43, 16411651, 2002.

Sinninghe Damsté, J. S., Ossebaar, J., Schouten, S., and Verschuren, D.: Altitudinal shifts in the branched tetraether lipid distribution in soil from Mt. Kilimanjaro (Tanzania): Implications for the MBT/CBT continental palaeothermometer, Org. Geochem., 39, 1072-1076, 2008.

Sinninghe Damsté, J. S., Ossebaar, J., Abbas, B., Schouten, S., and Verschuren, D.: Fluxes and distribution of tetraether lipids in an equatorial African lake: Constraints on the application of the TEX $_{86}$ palaeothermometer and BIT index in lacustrine settings, Geochim. Cosmochim. Ac., 73, 4232-4249, 2009.

Sinninghe Damsté, J. S., Rijpstra, W. I. C., Hopmans, E. C., Weijers, J. W. H., Foesel, B. U., Overmann, J., and Dedysh, S. N.: 13,16Dimethyl Octacosanedioic Acid (iso-Diabolic Acid), a Common Membrane-Spanning Lipid of Acidobacteria Subdivisions 1 and 3, Appl. Environ. Microbiol., 77, 4147-4154, 2011.

Smith, R. W., Bianchi, T. S., and Li, X.: A re-evaluation of the use of branched GDGTs as terrestrial biomarkers: Implications for the BIT Index, Geochim. Cosmochim. Ac., 80, 14-29, 2012.

Sofianos, S. S., Johns, W. E., and Murray, S. P.: Heat and freshwater budgets in the Red Sea from direct observations at Bab el Mandeb, Deep-Sea Res. Pt. II, 49, 1323-1340, 2002.

Sparkes, R. B., Dogrul Selver, A., Bischoff, J., Talbot, H. M., Gustafsson, Ö., Semiletov, I. P., Dudarev, O. V., and van Dongen, B. E.: GDGT distributions on the East Siberian Arctic Shelf: implications for organic carbon export, burial and degradation, Biogeosciences, 12, 3753-3768, doi:10.5194/bg-12-3753-2015, 2015.

Taylor, K. W. R., Huber, M., Hollis, C. J., Hernandez-Sanchez, M. T., and Pancost, R. D.: Re-evaluating modern and Palaeogene GDGT distributions: Implications for SST reconstructions, Global Planet. Change, 108, 158-174, 2013.

Tierney, J. E. and Russell, J.M.: Distributions of branched GDGTs in a tropical lake system: Implications for lacustrine application of the MBT/CBT paleoproxy, Org. Geochem., 40, 1032-1036, 2009.

Tierney, J. E., Schouten, S., Pitcher, A., Hopmans, E. C., and Sinninghe Damsté, J. S.: Core and intact polar glycerol dialkyl glycerol tetraethers (GDGTs) in Sand Pond, Warwick, Rhode Island (USA): Insights into the origin of lacustrine GDGTs, Geochim. Cosmochim. Ac., 77, 561-581, 2012.

Trommer, G., Siccha, M., Meer, M. T. J. V. D., Schouten, S., Damsté, J. S. S., Schulz, H., Hemleben, C., and Kucera, M.: Distribution of Crenarchaeota tetraether membrane lipids in surface sediments from the Red Sea., Org. Geochem., 40, 724-731, 2009.

Walsh, E. M., Ingalls, A. E., and Keil, R. G.: Sources and transport of terrestrial organic matter in Vancouver Island fjords and the Vancouver-Washington Margin: A multiproxy approach using d13Corg, lignin phenols, and the ether lipid BIT index, Limnol. Oceanogr., 53, 1054-1063, 2008. 
Weijers, J. W. H., Schouten, S., Spaargaren, O. C., and Sinninghe Damsté, J. S.: Occurrence and distribution of tetraether membrane lipids in soils: Implications for the use of the $\mathrm{TEX}_{86}$ proxy and the BIT index, Org. Geochem., 37, 1680-1693, 2006.

Weijers, J. W. H., Schefuß, E., Schouten, S., and Damsté, J. S. S.: Coupled thermal and hydrological evolution of tropical Africa over the last deglaciation, Science, 315, 1701-1704, 2007a.

Weijers, J. W. H., Schouten, S., Donker, J. C. V. D., Hopmans, E. C., and Damsté, J. S. S.: Environmental controls on bacterial tetraether membrane lipid distribution in soils, Geochim. Cosmochim. Ac., 71, 703-713, 2007b.

Weijers, J. W. H., Schefuß, E., Kim, J.-H., Sinninghe Damsté, J. S., and Schouten, S.: Constraints on the sources of branched tetraether membrane lipids in distal marine sediments, Org. Geochem., 72, 14-22, 2014.

White, D. C., Davis, W. M., Nickels, J. S., King, J. D., and Bobbie, R. J.: Determination of the sedimentary microbial biomass by extractible lipid phosphate, Oecologia, 40, 51-62, 1979.

Wu, W., Zhao, L., Pei, Y., Ding, W., Yang, H., and Xu, Y.: Variability of tetraether lipids in Yellow River-dominated continental margin during the past eight decades: Implications for organic matter sources and river channel shifts, Org. Geochem., 60, 3339, 2013.

Wu, W., Ruan, J., Ding, S., Zhao, L., Xu, Y., Yang, H., Ding, W., and Pei, Y.: Source and distribution of glycerol dialkyl glycerol tetraethers along lower Yellow River-estuary-coast transect, Mar. Chem., 158, 17-26, 2014.

Xiao, W., Xu, Y., Ding, S., Wang, Y., Zhang, X., Yang, H., Wang, G., and Hou, J.: Global calibration of a novel, branched GDGTbased soil pH proxy, Org. Geochem., 89, 56-60, 2015.

Yang, G., Zhang, C. L., Xie, S., Chen, Z., Gao, M., Ge, Z., and Yang, Z.: Microbial glycerol dialkyl glycerol tetraethers lipids from water and soil at the Three Gorges Dam on the Yangtze River, Org. Geochem., 56, 40-50, 2013.
Yang, H., Pancost, R. D., Dang, X., Zhou, X., Evershed, R. P., Xiao, G., Tang, C., Gao, L., Guo, Z., and Xie, S.: Correlations between microbial tetraether lipids and environmental variables in Chinese soils: Optimizing the paleo-reconstructions in semi-arid and arid regions, Geochim. Cosmochim. Ac., 126, 49-69, 2014a.

Yang, H., Pancost, R. D., Tang, C., Ding, W., Dang, X., and Xie, S.: Distributions of isoprenoid and branched glycerol dialkanol diethers in Chinese surface soils and a loess-paleosol sequence: Implications for the degradation of tetraether lipids, Org. Geochem., 66, 70-79, 2014b.

Zell, C., Kim, J.-H., Hollander, D., Lorenzoni, L., Baker, P., Silva, C. G., Nittrouer, C., and Sinninghe Damsté, J. S.: Sources and distributions of branched and isoprenoid tetraether lipids on the Amazon shelf and fan: Implications for the use of GDGT-based proxies in marine sediments, Geochim. Cosmochim. Ac., 139, 293-312, 2014.

Zell, C., Kim, J.-H., Dorhout, D., Baas, M., and Sinninghe Damsté, J. S.,: Sources and distributions of branched tetraether lipids and crenarchaeol along the Portuguese continental margin: Implications for the BIT index, Cont. Shelf. Res., 96, 34-44, 2015.

Zhang, Y. G., Zhang, C. L., Liu, X.-L., Li, L., Hinrichs, K.-U., and Noakes, J. E.: Methane Index: A tetraether archaeal lipid biomarker indicator for detecting the instability of marine gas hydrates, Earth Planet. Sc. Lett., 307, 525-534, 2011.

Zhu, C., Weijers, J. W. H., Wagner, T., Pan, J. M., Chen, J. F., and Pancost, R. D.: Sources and distributions of tetraether lipids in surface sediments across a large river-dominated continental margin, Org. Geochem., 42, 376-386, 2011.

Zhu, C., Wakeham, S. G., Elling, F. J., Basse, A., Mollenhauer, G., Versteegh, G. J. M., ouml, nneke, M., and Hinrichs, K. U.: Stratification of archaeal membrane lipids in the ocean and implications for adaptation and chemotaxonomy of planktonic archaea, Environ. Microbiol., doi:10.1111/1462-2920.13289, 2016. 